\title{
GENETIC DIVERSITY AND SELECTION IN TOMATO GENOTYPES UNDER WATER STRESS INDUCED BY MANNITOL
}

\author{
DIVERSIDADE GENÉTICA E SELEÇÃO EM GENÓTIPOS DE TOMATEIRO SOB \\ ESTRESSE HÍDRICO INDUZIDO POR MANITOL
}

\author{
Monique Ellis Aguilar BORBA ${ }^{\mathbf{1}}$ Gabriel Mascarenhas MACIEL ${ }^{2}$; \\ Guilherme Repeza MARQUEZ ${ }^{3}$; Eusímio Felisbino FRAGA JÚNIOR ${ }^{4}$; \\ Gregory Gustavo Silva NOGUEIRA ${ }^{5}$
}

1. Mestre em Fitotecnia pela Universidade Federal de Uberlândia, Uberlândia, MG, Brasil. monick1212@ hotmail.com; 2. Professor e Pesquisador da Universidade Federal de Uberlândia, Instituto de Ciências Agrárias, Monte Carmelo, MG, Brasil, gabrielmaciel@ufu.br; 3. Mestrando em Produção Vegetal pela Universidade Federal de Uberlândia, MG, Brasil; 4. Professor e Pesquisador da Universidade Federal de Uberlândia, Instituto de Ciências Agrárias, Monte Carmelo, MG, Brasil; 5. Graduando em Agronomia pela Universidade Federal de Uberlândia, Monte Carmelo, MG, Brasil.

\begin{abstract}
The tomato crop adapts to different climatic conditions. However, the water stress, which is a relevant factor in the tomato cropping, can affect the productivity. This experiment aimed to estimate the genetic variability, after two backcrosses, and select tomato genotypes that are tolerant to water stress induced by mannitol. The advance of the generations was done on the field and the water stress test was done in laboratory atmosphere, in a completely randomized design with four replications. 17 genotypes, in the generation $\mathrm{F}_{2} \mathrm{BC}_{2}$, which were obtained from an interespecific cross between Solanum pennellii and Solanum lycopersicum L. and three check treatments, one resistant [wild access LA-716 (Solanum pennellii)] and two susceptible ( $c v$. Santa Clara and UFU-650), were evaluated. After subjected to the osmotic potential of $-0.3 \mathrm{Mpa}$, the seeds were evaluated for: germination percentage, standard germination percentage, first counting percentage, germination velocity index, average time of germination and initial and final length of radicle. As expected, the wild access, S. pennellii, was better than the susceptible check treatments. The genotype UFU102/ $\mathrm{F}_{2} \mathrm{BC}_{2} \# 71115$ highlighted, compared to the others $\mathrm{F}_{2} \mathrm{BC}_{2}$ genotypes and in relation to the three check treatments, susceptible ( $c v$. Santa Clara and UFU-650) and resistant (S. pennellii). Analyzing the genetic diversity, 8 different groups were obtained, being an indicative of genetic variability between the evaluated genotypes. The variable $\% \mathrm{G}$ contributed with $33.9 \%$ in the diversification of the genotypes, presenting as the most important criterion, to be evaluated in genetic diversity studies, in the tomato crop under water stress, induced by mannitol.
\end{abstract}

KEYWORDS: Solanum pennellii. Solanum lycopersicum. Abiotic stress. Seeds. Seedlings.

\section{INTRODUCTION}

The tomato (Solanum lycopersicum L.) is a vegetable crop with high social and economic importance all over the world (HEINE et al. 2015). The crop adapts to different climatic conditions (ALVARENGA 2013), but the water stress, which is the moment when the absorption rate of water is lower than the loss rate (COSTA et al. 2008), is one of the major problems that affect the tomato yield. During the cropping, this vegetable needs, approach, $700 \mathrm{~mm}$ of water (de MELO et al. 2014) and, the inadequate supply of it might interfere on the development and productivity of the plants (Bray 2004).

In the last years, the conflicts about the use and water restrictions became a limiting factor, not only in arid and semi-arid regions, but also in places with high water content, but incapable to supply the high demand (TELLES; COSTA 2010). Because of that, the development of genotypes that are tolerant to water stress present as a good strategy of low cost and high efficiency in regions with drought (GIROTO et al. 2012).

Commercially, does not exist a genotype that has excellent agronomic characteristics and is also tolerant to water stress. This fact can be explained for the lack of efficient methodologies that are used to select the genotypes (BERENGUER 2015). The wild access LA-716, S. pennellii, is originating from a dry and hot region and because of the evolution over time, the specie is efficiency on the water use, compared to the common cultivars (ROCHA et al. 2016). Therefore, it is possible the introgression of genes, from $S$. pennellii, in advanced generations of tomato plants, aiming the development of genotypes that are tolerant to water stress.

The seed's germination in soils with low water potential depends on the characteristics of each species. In a laboratory atmosphere, it is possible to simulate the water stress through germination studies that use aqueous solutions of sucrose, salts, mannitol and polyethylene glycol. 
These solutes reduce the water potential when added to it and, allow the selection of tolerant genotypes (SANTOS et al. 1992).

The use of direct methods, in the selection for water stress, is expensive and demand long time, making the indirect methods more advantageous. The indirect method using mannitol, an inert chemical product and non-toxic (ECHER et al. 2010), has been widely used in different species, aiming simulate the water stress on laboratory atmosphere (COELHO et al. 2010, PELEGRINI et al. 2013, SOARES et al. 2015). According Berenguer (2015), the adequate osmotic potential, used for evaluate the water stress in tomato seeds and seedlings, is $-0.3 \mathrm{Mpa}$. However, the low genetic variability, combined with the high susceptibility that the current genotypes show, has made difficult to obtain advances on the tomato breeding programs.

This study aimed to estimate the genetic variability, after two backcrosses, and select tomato genotypes that are tolerant to water stress, induced by mannitol.

\section{MATERIAL AND METHODS}

The experiments were conducted on the laboratory of seeds analyze and genetic resources (LAGEN) and in the vegetable's experimental station of the Federal University of Uberlândia (UFU), both located on Monte Carmelo city (18 $42^{\prime} 43^{\prime \prime} \mathrm{S}$; $47^{\circ} 29^{\prime} 55^{\prime \prime}$; $873 \mathrm{~m}$ of altitude), in the period from January, 2013, to July, 2016.

In order to create a genetic variability, were realized an interespecific cross, in May 2013, between Solanum pennellii (wild access LA-716) versus Solanum lycopersicum L. (pre-commercial line UFU-650). The pre-commercial line belongs to the germplasm bank of the UFU and it has determinate growth habit, large fruits $(180 \mathrm{~g})$ of Santa Cruz type and is susceptible to water stress. The wild access, LA-716, has indeterminate growth habit, small fruits $(12 \mathrm{~g})$ and is tolerant to water stress (ROUSSEAUX et al. 2005, ROCHA et al. 2016). After the F1 generation (hybrids) were obtained, the first and second backcrosses were made, in 2014 and 2015, respectively. In January, 2016, a selfing of the $\mathrm{F}_{1} \mathrm{BC}_{2}$ was made, obtaining 17 genotypes $\mathrm{F}_{2} \mathrm{BC}_{2}$.

Aiming checking the germination, the seeds were submitted to a pre-test, named standard germination (SG), which did not has osmotic solution. The pre-test was design in a completely randomized system, with four replications of 25 seeds and 20 treatments, which were 17 genotypes
$\mathrm{F}_{2} \mathrm{BC}_{2}$ :

UFU102/ $\mathrm{F}_{2} \mathrm{BC}_{2} \# 71114$

UFU102/ $/ \mathrm{F}_{2} \mathrm{BC}_{2} \# 7117$;

$\mathrm{UFU} 102 / \mathrm{F}_{2} \mathrm{BC}_{2} \# 7912$;

UFU102/ $/ \mathrm{F}_{2} \mathrm{BC}_{2} \# 7917$;

$\mathrm{UFU} 102 / \mathrm{F}_{2} \mathrm{BC}_{2} \# 71813$;

UFU102/ $/ \mathrm{F}_{2} \mathrm{BC}_{2} \# 7189$;

$\mathrm{UFU} 102 / \mathrm{F}_{2} \mathrm{BC}_{2} \# 791$;

UFU102/ $\mathrm{F}_{2} \mathrm{BC}_{2} \# 7153$ and

three check treatments: a recurrent parent, UFU650; a donor parent, LA-716 and the $c v$. Santa Clara, totalizing 80 experimental plots, represented by plastic and transparent boxes (Gerbox).

After checking the SG, in each genotype, a new sowing was realized, aiming an indirect selection of the $\mathrm{F}_{2} \mathrm{BC}_{2}$ family, and a solution of mannitol $(-0.3 \mathrm{Mpa})$, which is an inert chemical product and non-toxic (Echer et al. 2010) used for simulate the water stress on laboratory atmosphere, was applied. The sowing of the treatments was realized in plastic and transparent boxes of $11 \mathrm{x} 11 \mathrm{x}$ $3.0 \mathrm{~cm}$ and, the seeds were placed on two papers of "Germitest" type, in a completely randomized design, with four replications of 50 seeds in each box. The substrate was previously moistened with mannitol solution $(-0.3 \mathrm{Mpa})$. The boxes were sealed with Parafilm ${ }^{\circledR}$, in order to reduce the water loss, and were put on a germination chamber, BOD type, with temperature of $25^{\circ} \mathrm{C}$ and 12 hours of photoperiod.

Seven variables were evaluated: germination percentage $(\% \mathrm{G})$, under the presence of osmotic solution of mannitol $(-0.3 \mathrm{Mpa})$, on the eleventh day after sowing. The seeds that produced a primary root were considered germinated. The results were expressed in average percentage, according to the number of normal plants. The second variable analyzed was the standard germination percentage (\%SG), which had not osmotic solution (check treatment), accounting the germination percentage. The third one was the first counting percentage $(\% \mathrm{FC})$, which was done together with the germination test. This analyze consisted in evaluate the percentage of normal plants that were checked in the first counting of the germination test and it was done on the fifth day after sowing (BRASIL 2009). The fourth variable analyzed were the germination velocity index (GVI), calculated by the sum of the germinated seeds in each day, divided by the number of days elapsed between sowing and germination. The fifth variable was the average time of germination (ATG), obtained by counting, every day, the germinated seeds, until the eleventh day after sowing. It was calculated using the equation: 
$\mathrm{ATG}=\sum\left(\mathrm{n}_{\mathrm{i}} \mathrm{t}_{\mathrm{i}}\right) / \sum \mathrm{n}_{\mathrm{i}}$, where $\mathrm{n}_{\mathrm{i}}$ is the number of germinated seeds in each count interval; $t_{i}$ is the elapsed time between the beginning of the germination and the last counting. The sixth variable analyzed was the initial length of radicle (IL, mm), measured with an aid of a millimeter ruler, on the fourth day after sowing, in the fifty plants considered normal on the boxes. The values were added and the average of each plot was obtained. The seventh and final variable analyzed was the final length of radicle (FL, $\mathrm{mm}$ ), that was also measured with an aid of a millimeter ruler, on the seventh day after sowing, in the fifty plants considered normal on the boxes. The values were also added and the average of each plot was obtained.

After checking the analyze of variance (ANOVA) assumptions, examining the normality distribution of the residuals (KolmogorovSmirnov's test) and homogeneity of variances (Levene's test), it was done an analyze of variance ( $F$ test, $p<0.01$ ) and, in case of a significant effect, the following tests were done: Scott-Knott test $(\mathrm{p}<$ 0.05 ); orthogonal contrasts of interest (Scheffé's test $\mathrm{p}<0.05$ and 0.01 ); relative contribution of the characters (SINGH 1981) and optimization grouping of Tocher. The statistic analyze was done with an aid of the computational program, GENES (CRUZ 2013).

\section{RESULTS AND DISCUSSION}

In the standard germination (SG), it was checked that the percentage of average germination, for all genotypes, were above 64\% (Table 1). It was checked an decreased in the germination percentage $(\% \mathrm{G})$, when the seeds were submitted to a water stress and, this was due to a reduction in water availability, required for activation and maintenance of the seeds metabolism (BEWLEY et al. 2013).

After the tomato seeds were inducted to a water stress's test, it was possible to verify a significant difference between the genotypes, when the variables (germination, first counting, germination velocity index, average time of germination, initial and final length of radicle) were analyzed (Table 1).

The wild access, S. pennellii, which is tolerant to water stress, significantly differed from the susceptible check treatment, UFU-650, for almost all analyzed variables, except for initial and final length of radicle. The wild specie also presented higher tolerance to water stress than the $c v$. Santa Clara and differed, significantly, for almost all variables, except for initial length of radicle. Considering the variables $\% \mathrm{G}$ and $\% \mathrm{FC}$ (Table 2), the wild access LA-716 (S. pennellii) showed superiority of $146.3 \%$ and $900 \%$, respectively, in relation to the $c v$. Santa Clara. When compared to the genotype UFU-650, the $S$. pennellii also showed superiority of $58.3 \%$ and $260 \%$ for the variables $\% \mathrm{G}$ and $\% \mathrm{FC}$, respectively. These results demonstrate that the water stress, induced by mannitol on the osmotic potential level of -0.3 Mpa, is efficient on the selection of tomato genotypes with tolerance to water stress. Custódio et al. (2009) verified in their worked that the potentials, 0 , $-0.3,-0.6$ and $-0.9 \mathrm{Mpa}$ of the solution, did not promote differences in the germination of bean seeds. On the other hand, Ávila et al. (2007), working with canola seeds, observed that the seeds showed satisfactory germination when submitted to osmotic potential of $-0.25 \mathrm{Mpa}$ and, after this potential level, the germination rate had reduced. The fact of the $c v$. Santa Clara showed one of the worst performance among the genotypes, confirms its susceptibility to a water stress. This fact can be confirmed analyzing the relative superiority (Table 2).

The genotypes UFU102/ $\mathrm{F}_{2} \mathrm{BC}_{2} \# 71115$ and UFU102/ $\mathrm{F}_{2} \mathrm{BC}_{2} \# 71114$ highlighted, showing higher tolerance to water stress than the others. They presented $238.9 \%$ and $237.0 \%$ of relative superiority, respectively, for $\% \mathrm{G}$ and $1533.1 \%$ and $1611.1 \%$, respectively, for $\% \mathrm{FC}$, compared to the cv. Santa Clara (Table 2). When compared to the access UFU-650, these genotypes also showed relative superiority of $117.9 \%$ and $116.7 \%$, for $\% \mathrm{G}$ and $488.0 \%$ and $516 \%$ for $\% \mathrm{FC}$, respectively. The genotypes UFU102/ $\mathrm{F}_{2} \mathrm{BC}_{2} \# 71115$ and UFU102/ $\mathrm{F}_{2} \mathrm{BC}_{2} \# 71114$ highlighted not only in relation to the two susceptible check treatments, they showed relative superiority of $37.6 \%$ and $36.8 \%$ for $\% \mathrm{G}$ and $63.3 \%$ and $71.1 \%$ for $\% \mathrm{FC}$, respectively, in relation to the donor parent, $S$. pennellii. It is worth mentioning that other genotypes also showed relative superiority in relation to the wild access, having the possibility to be used in a tomato breeding program.

After the contrasts were analyzed, it was observed that the $\mathrm{C} 1$ and $\mathrm{C} 3$ were not significantly. It demonstrates that the $\mathrm{F}_{2} \mathrm{BC}_{2}$ genotypes were similar to the wild access LA-716 (S. pennellii). Analyzing the $\mathrm{C} 2$, it was possible to verify that the average of the genotypes were mostly higher than the averages of the susceptible check treatments, $c v$. Santa Clara and UFU-650. After the C4 was evaluated, it was possible to verify that, for all variables analyzed, the average of the $\mathrm{F}_{2} \mathrm{BC}_{2}$ 
treatments was higher than the average of the genotypes UFU-650 and LA-716. The results obtained by the contrasts reinforce the efficiency in the use of mannitol, for selection tomato genotypes tolerant to water stress and indicate that the genotypes $\mathrm{UFU} 102 / \mathrm{F}_{2} \mathrm{BC}_{2} \# 71115$

UFU102/ $\mathrm{F}_{2} \mathrm{BC}_{2} \# 71114$ were superior than others in relation to water stress.

Table 1. Germination percentage $(\% \mathrm{G})$, first counting percentage $(\% \mathrm{FC})$, germination velocity index (GVI), average time of germination (ATG), initial length (IL) and final length (FL), in tomato genotypes under osmotic potential of $-0.3 \mathrm{Mpa}$, induced by mannitol and standard germination percentage (\%SG) without osmotic solution. Monte Carmelo city, Federal University of Uberlândia, 2016.

\begin{tabular}{|c|c|c|c|c|c|c|c|c|c|c|c|c|c|c|c|}
\hline \multirow{2}{*}{\multicolumn{2}{|c|}{$\begin{array}{l}\text { Genotype }(\mathrm{x}) \\
\text { UFU102/ } \mathrm{F}_{2} \mathrm{BC}_{2} \# 71115\end{array}$}} & \multirow{2}{*}{$\frac{\% \mathrm{G}}{91.5}$} & \multirow[b]{2}{*}{$\mathrm{a}$} & \multicolumn{2}{|c|}{$\%$ SG } & \multicolumn{2}{|c|}{$\% \mathrm{FC}$} & \multicolumn{2}{|l|}{ GVI } & \multicolumn{2}{|c|}{$\begin{array}{l}\text { ATG } \\
\text { (Days) }\end{array}$} & \multicolumn{2}{|c|}{ IL (mm) } & \multicolumn{2}{|c|}{$\begin{array}{l}\text { FL } \\
(\mathrm{mm})\end{array}$} \\
\hline & & & & 90.0 & $\mathrm{a}$ & 73.5 & a & 11.7 & $\mathrm{a}$ & 4.4 & $\mathrm{c}$ & 5.2 & a & 25.0 & a \\
\hline $\mathrm{T} 2$ & $\mathrm{UFU} 102 / \mathrm{F}_{2} \mathrm{BC}_{2} \# 71114$ & 91.0 & $\mathrm{a}$ & 92.0 & $\mathrm{a}$ & 77.0 & $\mathrm{a}$ & 11.3 & $\mathrm{a}$ & 4.6 & c & 4.2 & $\mathrm{a}$ & 21.5 & $\mathrm{a}$ \\
\hline $\mathrm{T} 3$ & $\mathrm{UFU} 102 / \mathrm{F}_{2} \mathrm{BC}_{2} \# 7118$ & 85.5 & a & 94.0 & a & 73.0 & $\mathrm{a}$ & 11.2 & a & 4.3 & c & 3.5 & $\mathrm{~b}$ & 19.2 & a \\
\hline $\mathrm{T} 4$ & UFU102/F $\mathrm{F}_{2} \mathrm{BC}_{2} \# 7117$ & 77.0 & $\mathrm{~b}$ & 83.0 & b & 61.5 & $\mathrm{a}$ & 9.4 & a & 4.8 & c & 4.4 & $\mathrm{a}$ & 15.5 & $\mathrm{~b}$ \\
\hline T5 & UFU102/F $\mathrm{F}_{2} \mathrm{BC}_{2} \# 7122$ & 76.0 & $\mathrm{~b}$ & 84.0 & $\mathrm{~b}$ & 39.5 & $\mathrm{~b}$ & 10.1 & a & 5.1 & $\mathrm{c}$ & 2.1 & c & 13.3 & $\mathrm{~b}$ \\
\hline T6 & $\mathrm{UFU} 102 / \mathrm{F}_{2} \mathrm{BC}_{2} \# 7912$ & 74.5 & $\mathrm{~b}$ & 91.0 & a & 44.0 & $\mathrm{~b}$ & 7.7 & $\mathrm{~b}$ & 5.7 & $\mathrm{~b}$ & 1.6 & c & 14.2 & $\mathrm{~b}$ \\
\hline $\mathrm{T} 7$ & $\mathrm{UFU} 102 / \mathrm{F}_{2} \mathrm{BC}_{2} \# 7139$ & 70.5 & $\mathrm{~b}$ & 88.0 & $\mathrm{a}$ & 50.0 & $\mathrm{~b}$ & 7.5 & $\mathrm{~b}$ & 5.2 & c & 2.5 & $\mathrm{~b}$ & 14.4 & b \\
\hline $\mathrm{T} 8$ & UFU102/F ${ }_{2} \mathrm{BC}_{2} \# 7917$ & 70.0 & $\mathrm{~b}$ & 85.0 & $\mathrm{~b}$ & 47.5 & $\mathrm{~b}$ & 8.0 & $\mathrm{~b}$ & 4.9 & $\mathrm{c}$ & 2.4 & $\mathrm{~b}$ & 16.9 & $\mathrm{~b}$ \\
\hline T9 & LA-716 & 66.5 & $\mathrm{~b}$ & 98.0 & $\mathrm{a}$ & 45.0 & $\mathrm{~b}$ & 7.6 & $\mathrm{~b}$ & 5.2 & $\mathrm{c}$ & 1.0 & d & 9.3 & c \\
\hline $\mathrm{T} 10$ & $\mathrm{UFU} 102 / \mathrm{F}_{2} \mathrm{BC}_{2} \# 7714$ & 65.0 & $\mathrm{~b}$ & 73.0 & b & 50.0 & $\mathrm{~b}$ & 7.6 & $\mathrm{~b}$ & 4.9 & $\mathrm{c}$ & 3.3 & b & 10.1 & $\mathrm{c}$ \\
\hline T11 & $\mathrm{UFU} 102 / \mathrm{F}_{2} \mathrm{BC}_{2} \# 71813$ & 53.5 & c & 77.0 & b & 40.0 & b & 8.1 & b & 4.8 & c & 2.6 & b & 7.8 & c \\
\hline $\mathrm{T} 12$ & UFU102/ $\mathrm{F}_{2} \mathrm{BC}_{2} \# 71111$ & 53.0 & $\mathrm{c}$ & 81.0 & $\mathrm{~b}$ & 27.5 & $\mathrm{c}$ & 4.9 & $\mathrm{c}$ & 5.9 & $\mathrm{~b}$ & 0.3 & $\mathrm{~d}$ & 8.5 & c \\
\hline $\mathrm{T} 13$ & $\mathrm{UFU} 102 / \mathrm{F}_{2} \mathrm{BC}_{2} \# 7189$ & 49.0 & c & 71.0 & $\mathrm{~b}$ & 26.5 & $\mathrm{c}$ & 5.4 & c & 5.7 & b & 2.0 & c & 6.8 & c \\
\hline T14 & $\mathrm{UFU} 102 / \mathrm{F}_{2} \mathrm{BC}_{2} \# 71013$ & 49.0 & $\mathrm{c}$ & 67.0 & c & 19.5 & c & 5.3 & $\mathrm{c}$ & 6.1 & b & 0.5 & d & 4.3 & d \\
\hline $\mathrm{T} 15$ & UFU-650 & 42.0 & $\mathrm{c}$ & 88.0 & $\mathrm{a}$ & 12.5 & $\mathrm{~d}$ & 3.5 & d & 6.4 & $\mathrm{~b}$ & 0.3 & d & 6.0 & $\mathrm{c}$ \\
\hline T16 & $\mathrm{UFU} 102 / \mathrm{F}_{2} \mathrm{BC}_{2} \# 791$ & 38.5 & $\mathrm{~d}$ & 65.0 & c & 17.5 & c & 4.7 & c & 5.7 & b & 0.8 & d & 5.8 & c \\
\hline $\mathrm{T} 17$ & $\mathrm{UFU} 102 / \mathrm{F}_{2} \mathrm{BC}_{2} \# 7812$ & 36.5 & $\mathrm{~d}$ & 81.0 & $\mathrm{~b}$ & 17.5 & $\mathrm{c}$ & 3.3 & $\mathrm{~d}$ & 6.3 & $\mathrm{~b}$ & 0.3 & d & 1.7 & d \\
\hline T18 & $\mathrm{UFU} 102 / \mathrm{F}_{2} \mathrm{BC}_{2} \# 7185$ & 29.5 & $\mathrm{~d}$ & 64.0 & $\mathrm{c}$ & 20.0 & $\mathrm{c}$ & 4.1 & $\mathrm{c}$ & 5.4 & $\mathrm{c}$ & 1.2 & $\mathrm{c}$ & 2.5 & d \\
\hline T19 & $\mathrm{UFU} 102 / \mathrm{F}_{2} \mathrm{BC}_{2} \# 7153$ & 29.0 & $\mathrm{~d}$ & 93.0 & $\mathrm{a}$ & 5.0 & d & 2.2 & d & 7.4 & a & 0.1 & d & 2.6 & d \\
\hline T20 & $c v$. SantaClara & 27.0 & $\mathrm{~d}$ & 83.0 & b & 4.5 & d & 2.1 & $\mathrm{~d}$ & 7.2 & a & 0.2 & d & 3.2 & d \\
\hline
\end{tabular}

\begin{tabular}{|c|c|c|c|c|c|c|c|c|}
\hline \multicolumn{3}{|c|}{ Contrasts of Interest (y) } & \multicolumn{6}{|c|}{ Estimating Contrasts } \\
\hline $\mathrm{C} 1=$ & $\begin{array}{c}{[(\mathrm{T} 1+\mathrm{T} 2+\mathrm{T} 3+\mathrm{T} 4+\mathrm{T} 5+\mathrm{T} 6} \\
+\mathrm{T} 7+\mathrm{T} 8+\mathrm{T} 10+\mathrm{T} 11+\mathrm{T} 12 \\
+\mathrm{T} 13+\mathrm{T} 14+\mathrm{T} 16+\mathrm{T} 17+\mathrm{T} \\
18+\mathrm{T} 19) / 17)]-(\mathrm{T} 9)\end{array}$ & $5.4^{\mathrm{ns}}$ & $16.9^{\mathrm{ns}}$ & $4.4^{\mathrm{ns}}$ & $0.4^{\mathrm{ns}}$ & $0.2^{\mathrm{ns}}$ & $1.2^{\mathrm{ns}}$ & $1.9^{\mathrm{ns}}$ \\
\hline $\mathrm{C} 2=$ & $\begin{array}{c}{[(\mathrm{T} 1+\mathrm{T} 2+\mathrm{T} 3+\mathrm{T} 4+\mathrm{T} 5+\mathrm{T} 6} \\
+\mathrm{T} 7+\mathrm{T} 8+\mathrm{T} 10+\mathrm{T} 11+\mathrm{T} 12 \\
+\mathrm{T} 13+\mathrm{T} 14+\mathrm{T} 16+\mathrm{T} 17+\mathrm{T} \\
\text { 18+T19/17)]- } \\
(\mathrm{T} 15+\mathrm{T} 20 / 2)\end{array}$ & $26.6^{* *}$ & $4.4^{\mathrm{ns}}$ & $32.1^{* *}$ & $4.4^{* *}$ & $1.5^{* *}$ & $1.9^{\mathrm{ns}}$ & $6.6^{\mathrm{ns}}$ \\
\hline $\mathrm{C} 3=$ & {$[(\mathrm{T} 1+\mathrm{T} 2 / 2)]-(\mathrm{T} 9)$} & $24.8^{\text {ns }}$ & $7.0^{\mathrm{ns}}$ & $30.3^{\text {ns }}$ & $3.9^{\text {ns }}$ & $0.7^{\mathrm{ns}}$ & $3.7^{*}$ & $14.0^{* *}$ \\
\hline $\mathrm{C} 4=$ & $\begin{array}{l}{[(\mathrm{T} 1+\mathrm{T} 2 / 2)]-} \\
(\mathrm{T} 15+\mathrm{T} 20 / 2)\end{array}$ & $56.8^{* *}$ & $5.5^{\mathrm{ns}}$ & $66.8^{* *}$ & $8.7^{* *}$ & $2.3^{* *}$ & $4.4^{* *}$ & $18.6^{* *}$ \\
\hline
\end{tabular}

(x) Means followed by the same letter in the column did not differ, significantly, from each other, by Scott-Knott test, $\mathrm{p}<0.05$ and ${ }^{(\mathrm{y})}$ **, * and ${ }^{\text {ns }}=$ significant $\alpha=0.01, \alpha=0.05$ and not significantly, respectively, by the Scheffé test. 
Table 2. Relative superiority of the $17 \mathrm{~F}_{2} \mathrm{BC}_{2}$ genotypes, in relation to the check treatments, wild access LA716 (S. pennellii), cv. Santa Clara and UFU-650. Monte Carmelo city, Federal University of Uberlândia, 2016.

\begin{tabular}{|c|c|c|c|c|c|c|c|}
\hline & Genotype & $\begin{array}{c}\text { RS (G\%) } \\
\text { LA-716 }\end{array}$ & $\begin{array}{c}\text { RS (FC\%) } \\
\text { LA-716 }\end{array}$ & $\begin{array}{l}\text { RS }(\mathrm{G} \%) c v . \\
\text { Santa Clara }\end{array}$ & $\begin{array}{l}\text { RS (FC\%) } c v . \\
\text { Santa Clara }\end{array}$ & $\begin{array}{l}\text { RS(G\%) } \\
\text { UFU-650 }\end{array}$ & $\begin{array}{l}\text { RS (FC\%) } \\
\text { UFU-650 }\end{array}$ \\
\hline T1 & UFU102/ $\mathrm{F}_{2} \mathrm{BC}_{2} \# 71115$ & 37.6 & 63.3 & 238.9 & 1533.3 & 117.9 & 488.0 \\
\hline $\mathrm{T} 2$ & UFU102/ $\mathrm{F}_{2} \mathrm{BC}_{2} \# 71114$ & 36.8 & 71.1 & 237.0 & 1611.1 & 116.7 & 516.0 \\
\hline $\mathrm{T} 3$ & UFU102/ $\mathrm{F}_{2} \mathrm{BC}_{2} \# 7118$ & 28.6 & 62.2 & 216.7 & 1522.2 & 103.6 & 484.0 \\
\hline $\mathrm{T} 4$ & UFU102/ $\mathrm{F}_{2} \mathrm{BC}_{2} \# 7117$ & 15.8 & 36.7 & 185.2 & 1266.7 & 83.3 & 392.0 \\
\hline T5 & UFU102/ $\mathrm{F}_{2} \mathrm{BC}_{2} \# 7122$ & 14.3 & -12.2 & 181.5 & 777.8 & 81.0 & 216.0 \\
\hline T6 & UFU102/ $\mathrm{F}_{2} \mathrm{BC}_{2} \# 7912$ & 12.0 & -2.2 & 175.9 & 877.8 & 77.4 & 252.0 \\
\hline $\mathrm{T} 7$ & UFU102/ $\mathrm{F}_{2} \mathrm{BC}_{2} \# 7139$ & 6.0 & 11.1 & 161.1 & 1011.1 & 67.9 & 300.0 \\
\hline $\mathrm{T} 8$ & UFU102/ $\mathrm{F}_{2} \mathrm{BC}_{2} \# 7917$ & 5.3 & 5.6 & 159.3 & 955.6 & 66.7 & 280.0 \\
\hline T9 & LA-716 & 0.0 & 0.0 & 146.3 & 900.0 & 58.3 & 260.0 \\
\hline $\mathrm{T} 10$ & UFU102/ $\mathrm{F}_{2} \mathrm{BC}_{2} \# 7714$ & -2.3 & 11.1 & 140.7 & 1011.1 & 54.8 & 300.0 \\
\hline $\mathrm{T} 11$ & UFU102/ $\mathrm{F}_{2} \mathrm{BC}_{2} \# 71813$ & -19.5 & -11.1 & 98.1 & 788.9 & 27.4 & 220.0 \\
\hline $\mathrm{T} 12$ & UFU102/ $\mathrm{F}_{2} \mathrm{BC}_{2} \# 71111$ & -20.3 & -38.9 & 96.3 & 511.1 & 26.2 & 120.0 \\
\hline $\mathrm{T} 13$ & UFU102/ $\mathrm{F}_{2} \mathrm{BC}_{2} \# 7189$ & -26.3 & -41.1 & 81.5 & 488.9 & 16.7 & 112.0 \\
\hline T14 & UFU102/ $\mathrm{F}_{2} \mathrm{BC}_{2} \# 71013$ & -26.3 & -56.7 & 81.5 & 333.3 & 16.7 & 56.0 \\
\hline $\mathrm{T} 15$ & UFU-650 & -36.8 & -72.2 & 55.6 & 177.8 & 0.0 & 0.0 \\
\hline T16 & $\mathrm{UFU} 102 / \mathrm{F}_{2} \mathrm{BC}_{2} \# 791$ & -42.1 & -61.1 & 42.6 & 288.9 & -8.3 & 40.0 \\
\hline $\mathrm{T} 17$ & $\mathrm{UFU} 102 / \mathrm{F}_{2} \mathrm{BC}_{2} \# 7812$ & -45.1 & -61.1 & 35.2 & 288.9 & -13.1 & 40.0 \\
\hline $\mathrm{T} 18$ & UFU102/ $\mathrm{F}_{2} \mathrm{BC}_{2} \# 7185$ & -55.6 & -55.6 & 9.3 & 344.4 & -29.8 & 60.0 \\
\hline T19 & UFU102/ $\mathrm{F}_{2} \mathrm{BC}_{2} \# 7153$ & -56.4 & -88.9 & 7.4 & 11.1 & -31.0 & -60.0 \\
\hline $\mathrm{T} 20$ & cv. SantaClara & -59.4 & -90.0 & 0.0 & 0.0 & -35.7 & -64.0 \\
\hline
\end{tabular}

Based on the cluster analyze of the optimization method of Tocher (Table 3), the genotypes were separated in five different groups, indicating variability between the evaluated materials. Nine genotypes were putted on the group I, with both susceptible check treatments, $c v$. Santa Clara and UFU-650, indicating that these genotypes are, potentially, susceptible to water stress.

The group II was composed by eight genotypes and inside of it, was the resistant check treatment, LA716 (S. pennellii), responsible for donate the genes that confer tolerance to water stress. Facing that, it is possible to state that the genotypes UFU102/ $/ \mathrm{F}_{2} \mathrm{BC}_{2} \# 7139, \quad \mathrm{UFU} 102 / \mathrm{F}_{2} \mathrm{BC}_{2} \# 7917$, UFU102/ $\mathrm{F}_{2} \mathrm{BC}_{2} \# 7912, \quad \quad \mathrm{UFU} 102 / \mathrm{F}_{2} \mathrm{BC}_{2} \# 7117$, UFU102/ $/ \mathrm{F}_{2} \mathrm{BC}_{2} \# 7714$, UFU102/ $/ \mathrm{F}_{2} \mathrm{BC}_{2} \# 7118$ and UFU102/ $\mathrm{F}_{2} B C_{2} \# 71114$ showed satisfactory levels of tolerance to water stress induced by mannitol. However, it does not indicate that these genotypes were better. Observing the average tests (Table 1), it is possible to verify that the genotype UFU102/ $/ \mathrm{F}_{2} \mathrm{BC}_{2} \# 71115$ highlighted, presenting the best results for all variables analyzed and because of that, stayed in an isolated group (III), which showed better characteristics than the group that had the donor parent, $S$. pennellii. Therefore, it is possible to say that the genotype UFU102- $\mathrm{F}_{2} \mathrm{BC}_{2}-71115$ is the most indicate in a future breeding program that aims obtaining tomato genotypes with satisfactory levels of tolerance to water stress. The agglomerated average of the groups (Table 4) revealed that the genotype UFU102/ $\mathrm{F}_{2} \mathrm{BC}_{2} \# 71115$, which was the only component of the group III, had the higher average for $\% \mathrm{G}$ (91.5), \% FC (73.5), GVI (11.7), IL 
$(5.2 \mathrm{~mm})$ and FL $(25.0 \mathrm{~mm})$ and also presented the lowest average time of germination (4.4 days).

Table 3. Grouping standard of 20 tomato genotypes, based on genetic diversity. Monte Carmelo city, Federal University of Uberlândia, 2016.

\begin{tabular}{|c|c|c|}
\hline Group & Number of genotypes & Genotypes \\
\hline I & 9 & $\begin{array}{l}\text { UFU102/ } / \mathrm{F}_{2} \mathrm{BC}_{2} \# 7153, c v . \text { Santa Clara, UFU } 650, \\
\text { UFU102/ } \mathrm{F}_{2} \mathrm{BC}_{2} \# 7812 \text {, UFU102/ } \mathrm{F}_{2} \mathrm{BC}_{2} \# 791, \mathrm{UFU} 102 / \mathrm{F}_{2} \mathrm{BC}_{2} \# 7189 \text {, } \\
\text { UFU102/ } \mathrm{F}_{2} \mathrm{BC}_{2} \# 71013 \text {, UFU102/ } \mathrm{F}_{2} \mathrm{BC}_{2} \# 71111 \text { and } \\
\text { UFU102/ } / \mathrm{F}_{2} \mathrm{BC}_{2} \# 7185\end{array}$ \\
\hline II & 8 & $\begin{array}{l}\text { UFU102/ } / \mathrm{F}_{2} \mathrm{BC}_{2} \# 7139, \mathrm{UFU} 102 / \mathrm{F}_{2} \mathrm{BC}_{2} \# 7917, \\
\text { UFU102/ } \mathrm{F}_{2} \mathrm{BC}_{2} \# 7912, \mathrm{UFU} 102 / \mathrm{F}_{2} \mathrm{BC}_{2} \# 7117, \\
\text { UFU102/ } / \mathrm{F}_{2} \mathrm{BC}_{2} \# 7714, \mathrm{LA}-716, \mathrm{UFU} 102 / \mathrm{F}_{2} \mathrm{BC}_{2} \# 7118 \text { and } \\
\text { UFU102/ } / \mathrm{F}_{2} \mathrm{BC}_{2} \# 71114\end{array}$ \\
\hline III & 1 & UFU102/ $\mathrm{F}_{2} \mathrm{BC}_{2} \# 71115$ \\
\hline IV & 1 & UFU102/ $\mathrm{F}_{2} \mathrm{BC}_{2} \# 71813$ \\
\hline $\mathrm{V}$ & 1 & UFU102/ $\mathrm{F}_{2} \mathrm{BC}_{2} \# 7122$ \\
\hline
\end{tabular}

Table 4. Agglomerated average of the groups, in function of six variables. Monte Carmelo city, Federal University of Uberlândia, 2016.

\begin{tabular}{lccccc}
\hline Variables & I & II & III & IV & V \\
\hline$\%$ G & 39.3 & 75.0 & 91.5 & 53.5 & 76.0 \\
$\%$ FC & 16.7 & 56.0 & 73.5 & 40.0 & 39.5 \\
GVI & 3.9 & 8.8 & 11.7 & 8.1 & 10.1 \\
ATG (days) & 6.2 & 4.9 & 4.4 & 4.8 & 5.1 \\
IL (mm) & 0.6 & 2.8 & 5.2 & 2.6 & 2.1 \\
FL (mm) & 4.6 & 15.1 & 25.0 & 7.8 & 13.3 \\
\hline
\end{tabular}

The group II, which was consisted of genotypes that are similar to the wild access $S$. pennellii, showed the second highest average for \%FC (56.0), IL (2.8 mm) and FL (15.1 mm). The group $\mathrm{V}$ presented the second highest average for $\% \mathrm{G}(76.0 \%)$, similar to the group II $(75 \%)$. The group I, which had as component the susceptible check treatments, showed the lowest averages for $\% \mathrm{G}, \% \mathrm{FC}, \mathrm{GVI}, \mathrm{IL}$ and FL, but it presented the highest average for ATG (days), which is an important variable for detecting how fast the seeds can germinate and, consequently, settle in a place (FERREIRA et al. 2001, BORGHETTI; FERREIRA 2004). According Kramer (1974), a decrease in the seedlings growth, under water stress, is due to a reduction on the expansion of existing cells. By lowering the pressure of turgor, the water stress affects the cellular growth and interferes on the metabolism, growth and establishment of the seedlings (JALEEL et al. 2009).

The variables with most relative contributions on the evaluation diversity of the genotypes (Table 5) were, according to the method of Singh (1981), \% germination, germination velocity index and final length.

The variable $\% \mathrm{G}$ contributed with $33.9 \%$ in the diversification of the genotypes, presenting as the most important criterion. Analyzing the average of the groups (Table 4) for $\% \mathrm{G}$, it is possible to verify that the genotypes were expressive distinct, having $39.3 \%$ on group I and $91.5 \%$ on group III of variability, making the variable an important factor in the selection of tomato genotypes with tolerance to water stress. 
Table 5. Relative contribution of the variables \% G, GVI, FL (mm), \%FC, ATG and IL (mm) for diversity analyze - SINGH(1981). Monte Carmelo city, Federal University of Uberlândia.

\begin{tabular}{ccc}
\hline Variable & S.J & $\%$ \\
\hline GV & 1.387 .8 & 33.9 \\
FL $(\mathrm{mm})$ & 771.5 & 18.9 \\
$\% \mathrm{FC}$ & 697.0 & 17.0 \\
ATG (days) & 518.3 & 12.7 \\
IL (mm) & 445.7 & 10.9 \\
\hline
\end{tabular}

Suggestion of variable for discard : IL

The characteristics that provided the minor contributions, with the lowest values of relative importance, were the percentage of first counting $(\% \mathrm{FC})$, average time of germination (ATG) and initial length (IL, mm). The variable IL had the lowest relative contribution, with only $6.6 \%$, making it a possible discard.

\section{CONCLUSIONS}

There was genetic variability between the evaluated genotypes.

The variable $\% \mathrm{G}$ was the most important criterion in the differentiation of the genotypes, after they were submitted to a water stress induced by mannitol.

The genotype UFU102/ $\mathrm{F}_{2} \mathrm{BC}_{2} \# 71115$ was the most tolerant to water stress, suggesting a future use of it in a tomato breeding program that aim obtaining genotypes with satisfactory levels of tolerance to water stress.

\section{ACKNOULEDGMENTS}

The authors would like to thank the Federal University of Uberlândia, CNPq and FAPEMIG, for the financial support on this research project.

RESUMO: O tomateiro é uma planta que se adapta a diferentes condições climáticas. No entanto, o estresse hídrico, considerado um importante fator no cultivo de tomate, pode afetar a produção. O objetivo do experimento foi estimar a variabilidade genética, após dois retrocruzamentos, e selecionar genótipos de tomateiro tolerantes ao estresse hídrico induzido por manitol. O avanço das gerações foi realizado no campo e o teste de estresse hídrico, feito no laboratório, em delineamento inteiramente casualizado com quatro repetições. Foram avaliados 17 genótipos, em geração $\mathrm{F}_{2} \mathrm{BC}_{2}$, oriundos de um cruzamento interespecífico entre o Solanum lycopersicum e o Solanum pennellii e três testemunhas, sendo uma resistente [acesso selvagem LA-716 (Solanum pennellii)] e duas suscetíveis ( $c v$. Santa Clara e UFU-650). Após serem submetidas ao potencial osmótico de -0.3 Mpa, as sementes foram avaliadas para: porcentagem de germinação, porcentagem de germinação padrão, porcentagem de primeira contagem, índice de velocidade de germinação, tempo médio de germinação e comprimento inicial e final de radícula. Como esperado, o acesso selvagem, S. pennellii, mostrou-se superior às testemunhas suscetíveis. $\mathrm{O}$ genótipo UFU102/ $\mathrm{F}_{2} \mathrm{BC}_{2} \# 71115$, destacou-se quando comparado aos outros genótipos $\mathrm{F}_{2} \mathrm{BC}_{2}$ e em relação às três testemunhas, tanto as suscetíveis (cv. Santa Clara e UFU-650) quanto a resistente (S. pennellii). Analisando a diversidade genética, foi possível a obtenção de oito grupos diferentes, sendo um indicativo de variabilidade genética entre os genótipos avaliados. A variável \% G contribuiu com 33.9\% na diferenciação dos genótipos, apresentando-se como o critério mais importante a ser avaliado, em estudos de divergência genética, na cultura do tomateiro, sob estresse hídrico induzido por manitol.

PALAVRAS-CHAVE: Solanum pennellii. Solanum lycopersicum. Estresse abiótico. Sementes. Plântulas.

\section{REFERENCES}

ALVAREnGA. M. A. R. Tomate: Produção em campo, em casa de vegetação e em hidroponia. 2. ed. Lavras: UFLA, 2013. 455p. 
ÁVILA, M. R. et al. Influência do estresse hídrico simulado com manitol na germinação de sementes e crescimento de plântulas de canola. Revista Brasileira de Sementes, Londrina, v. 29, n. 1, p. 98-106, 2007. https://doi.org/10.1590/S0101-31222007000100014

BERENGUER. A. F. Estresse hídrico induzido por manitol para seleção de genótipos de tomateiro. 2015. $20 \mathrm{f}$. Dissertação (Mestrado em Fitotecnia: Área de concentração Melhoramento genético) Universidade Federal de Uberlândia, Uberlândia, 2015.

BEWLEY, J. D. et al. Seeds: Physiology of development, germination and dormancy.3. ed. New York: Springer. 2013. 392 p. https://doi.org/10.1007/978-1-4614-4693-4

BORGHETTI, F.; FERREIRA, A. G. Interpretação de resultados de germinação. In: FERREIRA, A. G.; BORGHETTI, F. (Eds). Germinação: do básico ao aplicado. Porto Alegre: Artmed, p. 209-222, 2004.

BRASIL. Ministério da Agricultura, Pecuária e Abastecimento. Secretaria de Defesa Agropecuária. Regras para análise de sementes, Brasília. 2009, 395 p. Available in:

$<$ http://www.agricultura.gov.br/arq_editor/file/2946_regras_analise_sementes.pdf> Accessed in: 20 jun. 2016.

BRAY, E. A. Genes commonly regulated by water-deficit stress in Arabidopsis thaliana. Journal of Experimental Botany, Oxford, v. 55, n. 407, p. 2331-2341, 2004. https://doi.org/10.1093/jxb/erh270

COELHO, D. L. M. et al. Estresse hídrico com diferentes osmóticos em sementes de feijão e expressão diferencial de proteínas durante a germinação. Acta Scientiarum Agronomy, Maringá, v. 32, n. 03, p. 491499, 2010.

COSTA, R. C. L. et al. Biochemical and physiological responses in two Vigna unguiculata(L.) Walp. cultivars under water stress. Journal of Agronomy, New York, v. 7, n. 1, p. 98- 101, 2008.

https://doi.org/10.3923/ja.2008.98.101

CRUZ, C. D. GENES: A software package for analysis in experimental statistics and quantitative genetics. Acta Scientiarum Agronomy, Maringá, v. 35, n. 3, p. 271-276, 2013.

CUSTÓDIO, C. C.; SALOMÃO, G. R.; MACHADO NETO, N. B. Estresse hídrico na germinação e vigor de sementes de feijão submetidas à diferentes soluções osmóticas. Revista Ciência Agronômica, Fortaleza, v. 40, n. 4, p. 617-623, 2009.

de MELO. P. C. T. et al. Produção de sementes de tomate. In: NASCIMENTO. W. M. 1 ed. Produção de sementes de hortaliças, Brasília: Embrapa, v. 2, cap. 8, p. 235-266, 2014.

ECHER, F. R. et al. Estresse hídrico induzido por manitol em cultivares de algodão. Revista Ciência Agronômica, Fortaleza, v. 41, n. 4, p. 638-645, 2010. https://doi.org/10.1590/S1806-66902010000400018

FERREIRA, A. G. et al. Germinação de sementes de Asteraceae nativas no Rio Grande do Sul, Brasil. Acta Botanica Brasilica, São Paulo, v.15, n. 2, p. 231- 24, 2001. https://doi.org/10.1590/S010233062001000200009

GIROTTO, L. et al. Tolerância à seca de genótipos de trigo utilizando agentes indutores de estresse no processo de seleção. Revista Ceres, Viçosa, v. 59, n. 2, p. 192-199, 2012.

HEINE, A. J. M. et al. Número de haste e espaçamento na produção e qualidade do tomate. Scientia Plena, São Cristóvão, v. 11, n. 9, 2015.

JALEEL, C. A. et al. Antioxidant defense responses: physiological plasticity in higher plants under abiotic constraints. Acta Physiologiae Plantarum. v. 31, n. 3, p. 427-436, 2009. https://doi.org/10.1007/s11738-0090275-6 
KRAMER, P. J. Fifty years of progress in water relations research. Plant Physiology, Waterbury, v. 54, n. 4, p. 463-471, 1974. https://doi.org/10.1104/pp.54.4.463

PELEGRINI, L. L. et al. Efeito do estresse hídrico simulado com NaCl, manitol e PEG (6000) na germinação de sementes de Erythrina falcata, Benth. Ciência Florestal, v. 23, n. 2, p. 511-519, 2013. https://doi.org/10.5902/198050989295

ROCHA, D. K. et al. Seleção de genótipos de tomateiro submetidos ao estresse hídrico em função da expressão de características fisiológicas. Revista Brasileira de Ciências Agrárias, Recife. v. 11, n. 2, p. 80-84, 2016. https://doi.org/10.5039/agraria.v11i2a5369

ROUSSEAUX, M. C. et al. QTL analysis of fruit antioxidants in tomato using Lycopersicon pennellii introgression lines. Theoretical and Applied Genetics, v. 111, p. 1396-1408, 2005. https://doi.org/10.1007/s00122-005-0071-7

SANTOS, L. M. dos. et al. Efeito do estresse salino e hídrico na germinação e vigor de sementes de soja. Revista Brasileira de Sementes, Londrina, v. 14, n. 2, p. 189-194, 1992. https://doi.org/10.17801/01013122/rbs.v14n2p189-194

SINGH, D. The relative importance of characters affecting genetic divergence. Indian Journal of Genetic and Plant Breeding, New Delhi. v. 11, n. 2, p. 237-245, 1981.

SOARES, M. M. et al. Estresse hídrico e salino em sementes de soja classificadas em diferentes tamanhos. Pesquisa Agropecuária Tropical, Goiânia , v. 45, n. 4, p. 370-378. 2015. https://doi.org/10.1590/1983-40632015v4535357

TELLES, D. D.; COSTA, R. P. Reúso da água: Conceitos, teorias e práticas. $2^{\circ}$ ed. São Paulo, SP: 2010. 408 p. 